\title{
Sistem Informasi Manajemen Rantai Pasok Pariwisata Untuk Pembuatan Produk Wisata Pada Agen Tour \& Travel dengan Analisis Swot dan Metode Analytic Network Process (ANP)
}

\author{
Dwi Mustika Kusumawardani ${ }^{a}$, Eko Sediyono ${ }^{b}$ \\ ${ }^{a}$ Magister Sistem Informasi Universitas Diponegoro \\ ${ }^{\mathrm{b}}$ Magister Sistem Informasi Universitas Kristen Satya Wacana
}

Naskah Diterima : 30 September 2016; Diterima Publikasi : 30 Oktober 2016

DOI: $10.21456 /$ vol6iss2pp177-185

\begin{abstract}
The development of services company in tourism is increasing. Therefore each tour \& travel agent should be able to improve the quality of attractive and competitive products. This research builds a system analysis of supply chain management in the manufacturing of tour packages with SWOT analysis and Analytic Network Process (ANP). SWOT analysis is one way to decide marketing strategy for the company to able to face global competition. In this study, a SWOT analysis is used to select the best suppliers in tourism sector. Suppliers include: hotels, restaurants, attractions and accommodations. Combination of the best suppliers used as in one product of tour package. While the method of Analytic Network Process is used to rank the tour package has been obtained previously. In addition, this method is applied because it can provide information about the most influential of criteria in making tour package. This method conducted by looking at dependency relationship between among criteria. Then give them weight among criteria, sub-criteria and alternatives. The criteria used in the method of Analytic Network Process are: product, price, place and promotion. The results obtained from this research is the system analysis of supply chain management of tourism which capable of producing an attractive and competitive tour packages form of tour packages 1 with a value of 0.53 . In addition, this information system provides information that the most influential criteria in making tour package is the product criteria with a value of 0.30 . The next criterion which affects the making of attractive and competitive tour packages is price of criteria with a value of 0.28 .
\end{abstract}

Keywords : Management analysis system; Supply chain; Touris; SWOT; Analytic Network Process tection, Recognitioeature,

Abstrak

Perkembangan perusahaan jasa di bidang pariwisata semakin meningkat. Untuk itu setiap agen tour \& travel harus mampu meningkatkan kualitas produk yang menarik dan kompetitif. Penelitian ini membangun sebuah sistem analisis manajemen rantai pasok pariwisata dalam pembuatan paket wisata dengan analisis SWOT dan metode Analytic Network Process (ANP). Analisis SWOT merupakan salah satu cara untuk memutuskan strategi pemasaran agar perusahaan mampu menghadapi persaingan global. Dalam penelitian ini, analisis SWOT digunakan untuk memilih pemasok terbaik di bidang pariwisata. Pemasok-pemasok tersebut antara lain: hotel, restoran, objek wisata dan akomodasi. Kombinasi pemasok terbaik dijadikan dalam satu produk berupa paket wisata. Sedangkan metode Analytic Network Process digunakan untuk merankingkan paket wisata yang telah didapat sebelumnya. Selain itu metode ini diterapkan karena mampu memberikan informasi kriteria yang paling berpengaruh dalam pembuatan paket wisata. Metode ini dilakukan dengan melihat ketergantungan hubungan antarkriteria. Kemudian memberikan bobot antarkriteria, sub-kriteria, dan alternatif. Kriteria yang digunakan dalam metode Analytic Network Process yaitu: product, price, place, dan promotion. Hasil yang didapat dari penelitian ini yaitu sistem analisis manajemen rantai pasok di bidang pariwisata yang mampu menghasilkan paket wisata yang menarik dan kompetitif berupa paket wisata 1 dengan nilai sebesar 0,53 . Selain itu, sistem informasi ini memberikan informasi bahwa kriteria yang paling berpengaruh dalam pembuatan paket wisata adalah kriteria product dengan nilai 0,30 . Kriteria selanjutnya yang mempengaruhi dalam pembuatan paket wisata yang menarik dan kompetitif adalah kriteria price dengan nilai sebesar 0,28 .

Kata kunci : Analisis manajemen; Rantai pasok; Pariwisata; SWOT; Analytic Network Process

\section{Pendahuluan}

Agen perjalanan yang merupakan salah satu bisnis layanan yang sangat berhubungan dengan pelayanan

*) Penulis korespondensi: renaissance17.galz@gmail.com berwisata berperan sebagai bagian utama dalam berinteraksi dengan pelanggan dan sebagai perantara utama antara rekan kerja perjalanan wisata dengan konsumen. Agen perjalanan bertanggung jawab untuk 
memberikan layanan pelanggan yang memainkan peran penting dalam keberhasilan agen perjalanan wisata (Cheyne et al., 2006). Kerjasama jangka panjang antara rekan kerja dalam bidang pariwisata dengan agen-agen perjalanan merupakan cara penting untuk memperluas agen tour \& travel yang besar secara geografis. Hubungan tersebut merupakan alternatif strategis sebagai interaksi agen tour dengan agen perjalanan independen melalui transaksi pasar (Yevstafyev dan Yevstafyev, 2015).

Dalam persaingan bisnis saat ini, tidak sedikit perusahaan di bidang tour \& travel yang mulai mengarahkan perhatiannya yang awalnya hanya berfokus pada pengembangan produk sampai layanan yang unggul ke arah penciptaan pengalaman personel konsumen. Peningkatan kualitas suatu perusahaan tour \& travel dapat dilihat dari teknologi yang mereka gunakan untuk mempromosikan dan mengenalkan perusahaan mereka kepada masyarakat. Selain itu, mereka juga meningkatkan daya saingnya dalam hal manajemen rantai pasok pariwisata yang efektif. Pemilihan pemasok pada dasarnya adalah masalah keputusan yang melibatkan kriteria majemuk (Kahraman, 2003).

Penelitian ini menggunakan ANP (Analytical Network Process) berbasis analisis SWOT (Strengths, Weaknesses, Opportunities, and Threats). Dengan menggunakan analisis SWOT akan diperoleh beberapa alternatif strategi yang diperlukan yang saling memiliki keterkaitan antar alternatif. Alternatif yang diperoleh perlu dibobotkan karena setiap alternatif memiliki tingkat kepentingan yang berbeda satu sama lain. ANP dalam penelitian ini digunakan untuk menentukan produk wisata. Dengan demikian dapat diperoleh alternatif strategi yang paling tepat digunakan dalam penentuan produk wisata yang kompetitif, menarik dan biaya terjangkau. Hal tersebut guna memenuhi keinginan calon wisatawan dalam memperoleh kepuasan dalam pelayanan agen tour \& travel yang mereka pilih dalam melakukan perjalanan wisata.

Metode Analytic Network Process (ANP) sendiri merupakan pengembangan dari metode Analytic Hierarchy Process (AHP), yang menggunakan ketergantungan antar unsur-unsur hirarki sebagai bahan pertimbangan. Terdapat beberapa masalah dalam pengambilan keputusan yang tidak dapat terstruktur secara hirarki karena melibatkan interaksi ketergantungan antara elemen tingkat yang lebih tinggi dengan elemen tingkat yang lebih rendah di dalam hirarkinya. Dibandingkan dengan AHP, ANP memiliki sintesis lebih dalam terhadap faktor atau kriteria keputusan, kelebihan lainnya adalah memberikan hasil perbandingan yang lebih objektif, kemampuan prediktif yang lebih akurat, dan hasil yang lebih stabil (Tanjung dan Devi, 2013). Metode ANP lebih umum diaplikasikan dalam berbagai hal seperti masalah pengambilan keputusan, alokasi sumberdaya, strategi, peramalan, evaluasi, dan lainnya. Pembuatan produk wisata tidak sederhana dan dengan cara manual tetapi diperlukan perbandingan kriteria. Maka untuk membantu pengambilan keputusan dalam pembuatan produk wisata ini, sangatlah sesuai jika diaplikasikan dengan menggunakan metode ANP.

Analisa SWOT merupakan salah satu cara dalam menyusun strategi perusahaan atau organisasi. Analisis SWOT dapat dilakukan dengan cara menggambarkan kondisi, bisa juga dengan cara mengevaluasi suatu masalah. Proyek atau konsep bisnis yang digunakan berdasarkan faktor internal (dalam) dan faktor eksternal (luar) yaitu Strengths, Weakness, Opportunities dan Threats yang ada. Ada beberapa macam analisis yang lain yang dapat digunakan untuk evaluasi. Diantaranya ada ISO, Balance Score Card dan lain sebagainya. Tetapi, analisis SWOT paling sering dan paling sesuai digunakan dalam evaluasi bisnis untuk mencari strategi yang akan dilakukan. Analisis SWOT juga memiliki banyak keunggulan dibandingkan pendekatan yang lain yaitu dengan analisis SWOT maka dapat diketahui situasi agen tour \& travel dengan cara mengidentifikasi faktor eksternal dan faktor internal yang dapat mempengaruhinya. Caranya adalah dengan menganalisis peluang dan kekuatan yang dimiliki untuk digunakan dalam penentuan rencana masa depan dan mengatasi kelemahan dan ancaman yang ada dalam perusahaan dengan cara rencana perbaikan yang akan dilakukan. Analisis SWOT merupakan suatu identifikasi berbagai faktor secara sistematis untuk merumuskan strategi perusahaan (Rangkuti, 2006).

Aplikasi yang dibangun dengan metode ANP dan SWOT ini, diharapkan mampu mengatasi masalah konsumen dalam memilih produk wisata agen tour \& travel sesuai dengan kriteria yang diinginkan. Dari permasalahan yang dihadapi konsumen dalam memilih produk wisata agen tour \& travel masih diperlukan suatu sistem informasi yang dapat membantu dalam pengambil keputusan dengan mengacu kepada kriteria-kriteria yang didapatkan dari analytic network process dengan berdasar pada analisis SWOT.

\section{Kerangka Teori}

Metode Fuzzy ANP digunakan dalam pedukung pengambilan keputusan suatu kasus pada pemilik kartu GSM dengan lima kriteria dan beberapa subkriteria yang ditentukan untuk memilih kartu GSM yang sesuai dengan keinginan pengguna. (Erginel dan Senturk, 2011). Pada penerapan Fuzzy ANP yang lain menjelaskan bahwa pendekatan metode Fuzzy ANP digunakan untuk permasalahan yang terdiri dari beberapa kiteria dan sub kriteria (Khodaverdi et al., 2008). Dalam penelitian ini akan digunakan analisis SWOT dan metode ANP dengan menggunakan empat kriteria yang digunakan dalam pembuatan produk wisata.

Berbagai metode dapat digunakan dalam permasalahan pemilihan rekan kerja yang melibatkan banyak kriteria. Melakukan pembobotan multi kriteria 
dalam pemilihan pemasok menggunakan metode Data Envelopment Analysis (DEA) (Ng, 2008). Analytic Network Process (ANP) dan TOPSIS digunakan untuk menghasilkan bobot dan rangking pemasok sedangkan program linear digunakan untuk mengalokasikan permintaan setiap pemasok (Lin, 2011). Pengembangan strategi kompetitif dalam rantai pasok dengan menggunakan analisis SWOT untuk mendapatkan kerangka kriteria dan indikator pemilihan pemasok (Chen, 2011). Jika kriteria yang akan digunakan untuk mengevaluasi pemasok mempunyai hubungan keterkaitan maka metode yang tepat digunakan adalah ANP (Dewayana dan Budi, 2009).

Penerapan ilmu baru tentang tujuan wisata gunung terkemuka di Swedia dengan menggunakan pendekatan Business Intelligence, ditujukan kepada agen pariwisata agar memperoleh pengetahuan yang baru mengenai pelanggan atau calon wisatawan berdasarkan proses tujuan wisata dengan menitik beratkan kepada tahap - tahap sebelum dan sesudah melakukan wisata. Dalam penelitian lain dijelaskan bahwa perencanaan strategis tetap menjadi alat manajemen yang paling populer. Penelitian ini membahas adanya kesenjangan dan review tentang penelitian perencanaan strategis dari perhotelan dan pariwisata secara up to date. Dalam penelitian ini dikatakan bahwa penelitian akademik yang dilakukan belum sejalan dengan prakteknya. Beberapa metode baru dalam meneliti lingkungan pariwisata juga dituangkan dalam penelitian ini.

Pariwisata merupakan kegiatan yang bersifat dinamis yang di dalamnya melibatkan lebih dari satu manusia dan mengikutsertakan berbagai bidang jasa dan usaha. Dalam Undang-Undang RI nomor 10 tahun 2009 tentang Kepariwisataan dijelaskan mengenai wisata, wisatawan, pariwisata, kepariwisataan, usaha pariwisata, pengusaha pariwisata, dan industri pariwisata. Jasa biro perjalanan wisata diwajibkan menyelenggarakan kegiatan pokok sebagai berikut:

1. Perencanaan dan pengemasan komponenkornponen perjalanan wisata, yang meliputi sarana wisata, obyek dan daya larik wisata serta jasa pariwisata lainnya yang terdapat di wilayah Indonesia dan belahan dunia dalam bentuk paket wisata

2. Penyelenggaraan dan penjualan paket wisata dengan cara menyalurkan melalui agen perjalanan wisata dan atau menjualnya langsung kepada wisatawan atau konsumen

3. Menyediakan layanan pramuwisata yang memiliki lisensi yang berhubungan dengan penjualan paket wisata

4. Penyelenggaraan perjalanan ibadah agama seperti haji, umroh dan hollyland, yang dilakukan sesuai dengan ketentuan perundang-undangan. Khusus untuk hollyland tour, harus mendapat persetujuan terlebih dahulu dari Kepala Dinas Pariwisata dan Kebudayaan

5. Penyelenggaraan perjalanan insentif
6. Penyelenggaraan perjalanan wisata lansia

7. Menyediakan layanan angkutan wisata

8. Melayani pemesanan akomodasi, restoran dan tiket pertunjukan seni budaya serta kunjungan ke obyek dan daya tarik wisata

9. Melayani pengurusan dokumen perjalanan, berupa paspor, visa dan dokumen lainnya.

Sesuai dengan program kegiatan dari Dinas Kebudayaan dan Pariwisata, pembinaan dan pengawasan terhadap kegiatan usaha biro perjalanan wisata dilakukan oleh Dinas Kebudayaan dan Pariwisata. Pembinaan dan pengawasan yang dilakukan antara lain:

1. Sosialisasi peraturan perundang-undangan di bidang kepariwisataan dan peraturan lainnya yang berkaitan

2. Penilaian kelayakan bisnis/ usaha penyelenggaraan Jasa Biro Perjalanan Wisata

3. Pelatihan tenaga kerja industri pariwisata

4. Pemberian penghargaan Adikarya Wisata

5. Kegiatan lainnya di bidang industri pariwisata kepada penyelenggara yang berkaitan dengan upaya peningkatan kualitas pelayanan

6. Informasi yang berkaitan dengan upaya peningkatan pengelolaan bisnis/ usaha yang sehat dan kondusif.

Pembinaan terhadap biro jasa perjalanan wisata juga dapat dilakukan bersama dengan instansi terkait atau Asosiasi di bidang industri pariwisata.

Dinas Pariwisata dan Agen tour \& travel perlu mengawasi dan meningkatkan kualitas produk wisata dengan memperatikan pemasok-pemasok bidang kepariwisataan, pemasok yang dimaksud terdiri dari hotel, restoran, objek wisata dan akomodasi. Hotel yang baik dilihat dari beberapa hal, antara lain: servis hotel, lokasi hotel, dan fasilitas hotel. Hotel yang baik memiliki kualitas dan konsistensi servis yang membedakan antara hotel biasa dengan hotel terbaik. Untuk lokasi hotel yang baik berada pada lokasi yang strategis dan memiliki pemandangan yang indah. Sedangkan untuk fasilitas hotel yang baik dapat dilihat dari fasilitas yang disediakan. Semakin lengkap fasilitas yang dimiliki hotel tersebut semakin baik.

Restoran merupakan suatu bangunan komersial yang memberikan jasa pelayanan yang baik kepada tamu, baik dalam penawaran dan pemberian pelayanan berupa makanan maupun minuman (Atmodjo, 2010). Restoran yang baik harus memiliki kualitas pelayanan yang baik. Kualitas pelayanan berhubungan dengan produk, tenaga kerja, proses dan tugas serta lingkungan yang memenuhi kebutuhan dan harapan konsumen (Garvin dan David, 2001).

Pemasok lainnya yang digunakan dalam penelitian ini ialah objek wisata. Objek wisata yang baik memiliki kelengkapan fasilitas sarana dan prasarana yang baik pula. Sarana pariwisata merupakan vendor dalam pariwisata (perusahaan di bidang bisnis pariwisata, lingkungan objek wisata, dan instansi pemerintahan bidang pariwisata) yang memberikan pelayanan kepada wisatawan. Pelayanan tersebut 
diberikan secara langsung maupun tidak langsung yang hidup dan kehidupannya bergantung pada jumlah kedatangan wisatawan. Sedangkan prasarana dalam bidang pariwisata adalah fasilitas-fasilitas yang mendukung sarana pariwisata agar berkembang dan dapat memberikan pelayanan terbaik untuk memenuhi kepuasan dan kebutuhan wisatawan yang berbedabeda (Agung, 1996). Selain restoran, akomodasi juga menjadi pertimbangan sebagai salah satu pemasok yang digunakan dalam penelitian ini. Akomodasi yang baik harus memiliki sarana prasarana yang baik seperti lokasi yang strategis, memiliki tenaga ahli yang memadai dan berpengalaman, dan memiliki perizinan yang jelas (Mike, 2006).

Manajemen rantai pasok merupakan kegiatan yang dimulai dari pengadaan bahan baku, mengubah bahan baku menjadi setengah jadi, hingga menjadi bahan jadi yang siap disalurkan kepada konsumen. Menjadikan pemasok sebagai rekan kerja merupakan kunci yang efektif dalam manajemen rantai pasok sebagai strategi perusahaan dalam memenuhi permintaan pasar. Rantai pasok juga dapat diartikan sebagai gabungan beberapa organisasi yang saling berhubungan dengan tujuan yang sama. Tujuan dari rantai pasok itu sendiri adalah melakukan proses pengadaan dan perubahan barang mentah menjadai barang jadi.

Rantai pasok pariwisata dimulai dari pengadaan bahan baku yaitu pengadaan pemasok (hotel, restauran objek wisata, dan akomodasi) kemudian bahan (pemasok) diproses dengan memilih pemasok menggunakan analisis SWOT. Setelah itu merubah barang mentah tersebut menjadi barang jadi. Jadi proses selanjutnya adalah pembuatan paket wisata dengan melihat pemasok-pemasok yang telah dipilih melalui analisis SWOT.

Definisi pemasaran menurut Kotler adalah suatu proses sosial dan manajerial yang membuat individu dan kelompok memperoleh apa yang mereka butuhkan serta inginkan melalui penciptaan dan pertukaran timbal balik produk dan nilai dengan orang lain. Sehingga manajemen pemasaran dapat diartikan sebagai kegiatan majamen atau pengaturan manfaat pemasaran secara maksimal dengan tujuan untuk memperlancar kegiatan tukar menukar atau penyampaian baik barang maupun jasa dari produsen ke konsumen yang dapat memuaskan kedua pihak tersebut (Widjajanta et al., 2007).

Penawaran produk pariwisata merupakan salah satu kegiatan analisis dalam proses pemasaran pariwisata. Analisis produk wisata merupakan tujuan pariwisata yang ditawarkan kepada calon wisatawan. Promosi juga merupakan salah satu strategi pemasaran pariwisata dalam mengenalkan produk wisata yang dimiliki suatu daerah. Tujuannya adalah menginformasikan dan mengenalkan kepada masyarakat atau calon wisatawan tentang produk wisata suatu daerah. Sedangkan dalam pembuatan produk wisata, juga perlu mempertimbangkan harga dari produk yang ditawarkan (Fahmi, 2014). Dari beberapa literatur tersebut maka, kriteria yang digunakan dalam pemasaran pariwisata ini adalah product, price, place dan promotion.

Dalam proses analisis SWOT, harus memahami seluruh informasi dan kondisi suatu kasus, menganalisis situasi untuk mengetahui isu apa yang sedang terjadi dan memutuskan tindakan apa yang harus segera dilakukan utuk memecahkan masalah (Rangkuti, 2001). Kekuatan dan kelemahan dalam area fungsional bisnis selalu dimiliki oleh semua organisasi. Tidak ada perusahaan yang sama kuatnya atau lemahnya dalam semua area bisnis (David, 2008).

Langkah-langkah analisis SWOT:

1. Penyusunan dan Penentuan Faktor-faktor Strategis Eksternal dan Internal

2. Penyusunan dan perhitungan nilai bobot, rating dan skor untuk tabel faktor eksternal dan internal menggunakan skala berikut:

a. Nilai Bobot dimana,
$1,00=$ sangat penting
$0,75=$ penting
$0,50=$ standar
$0,25=$ tidak penting
$0,10=$ sangat tidak penting
b. Nilai Rating
$5=$ sangat baik
$4=$ baik
$3=$ netral (standar)
$2=$ tidak baik
$1=$ sangat tidak baik
c. Nilai Skor
Untuk perhitungan nilai skor menggunakan rumus:

$$
\mathrm{NS}=\mathrm{NB} \times \mathrm{NR}
$$

Dimana:
NS : Nilai Skor
NB : Nilai Bobot
NR : Nilai Rating

Analytic Network Process (ANP) sebagai salah satu metode terbaru yang merupakan pengembangan dari AHP yang digunakan untuk pengambilan keputusan dengan multi kriteria. Permasalahan dalam strategi rantai nilai untuk mendapatkan rekan kerja yang sesuai, dapat dijelaskan secara sistematis dengan metode ANP. Bagi pengambil keputusan, ANP dapat memberikan jalan untuk memperoleh banyak informasi. Dalam Analytical Network Process, responden membandingkan secara berpasangan elemen-elemen yang berdasarkan kriterianya mempunyai hubungan ketergantungan. Skala penilaian yang digunakan antara 1 sampai dengan 9, nilai 1 mempunyai arti bahwa kedua kriteria sama penting sedangkan nilai 9 mengartikan bahwa kriteria tersebut mendominasi seluruh kriteria (Jharkharia dan Shankar, 2005).

Ketergantungan fungsional yang memungkinkan terjadinya umpan balik antara klaster merupakan strukturisasi dari masalah. AHP digunakan untuk mengatasi masalah dengan jenis masalah yang memiliki ketidaktergantungan pada alternatif atau kriteria sedangkan metode ANP digunakan untuk 
menyelesaikan masalah yang memiliki ketergantungan antara alternatif atau kriteria yang satu dengan yang lain (Saaty, 1996).

Dalam penelitian ini, ANP digunakan sebagai pembobotan subkriteria dan kriteria. Langkah yang dilakukan adalah:

1. Pembuatan model dan penentuan keterkaitan antar kriteria / subkriteria.

Pembuatan model kualitas pelayanan yang mengacu pada analisis SWOT merupakan langkah awal dari proses ANP. Yang dimaksud model dalam metode ANP merupakan strukturisasi masalah. Setelah pembentukan model pemilihan pemasok untuk pembuatan produk wisata dibentuk langkah selanjutnya mencari keterkaitan baik antara kriteria ataupun subkriteria.

2. Membuat perbandingan berpasangan kriteria/subkriteria dan mencari nilai eigen.

Perbandingan berpasangan dilakukan baik untuk kriteria ataupun subkriteria. Penilaian perbandingan diterapkan dengan mengacu kepada skala Saaty. Jika perbandingan berpasangan sudah ditentukan, maka tahap selanjutnya adalah melakukan perhitungan agar didapatkan nilai eigen. Caranya adalah dengan proses perkalian matrik yang dilakukan beberapa kali sampai didapatkan perbedaan antara nilai eigen pertama dan nilai eigen kedua.

3. Menghitung konsistensi ratio (CR)

Jika perbandingan berpasangan telah ditentukan, maka perhitungan ratio konsistensi (CR) dilakukan dengan cara:

a. Melakukan perkalian matriks antar kriteria/subkriteria dengan cara mencari hasil kali antara nilai perbandingan berpasangan yang sudah ditentukan dengan nilai eigen

b. Hasil dari perkalian matriks kriteria di atas kemudian dibagi dengan nilai eigen lagi

c. Kemudian hasil bagi dari semua kriteria dijumlahkan, lalu hasil penjumlahan tersebut dibagi dengan jumlah subkriteria. Hasil nilainya disebut $\lambda$ max atau $\pi$

d. Menghitung Consistensi Index (CI) dengan rumus: $\mathrm{CI}=(\pi-\mathrm{n}) / \mathrm{n}$

Dimana $\mathrm{n}=$ banyaknya subkriteria

e. Menghitung Consistensi Ratio (CR) dengan rumus: $\mathrm{CR}=\mathrm{CI} / \mathrm{IR}$

Dimana:CR = Consistency Ratio

$\mathrm{CI}=$ Consistency Index

$\mathrm{IR}=$ Index Random

Index Random dapat dilihat pada Tabel 1.

Tabel 1. Index Random

\begin{tabular}{cc}
\hline Ukuran Matrix $(\mathrm{N})$ & Nilai IR \\
\hline 1,2 & 0.00
\end{tabular}

$\begin{array}{cc}3 & 0,58 \\ 4 & 0,90 \\ 5 & 1,12 \\ 6 & 1,24 \\ 7 & 1,32 \\ 8 & 1,41 \\ 9 & 1,45 \\ 10 & 1,49\end{array}$

Perhitungan dinyatakan benar jika konsistensi ratio (CR) kurang atau sama dengan $(<=0,1)$. Tetapi jika hasil nilai yang menunjukkan lebih besar dari $(>0,1)$ berarti harus ada perbaikan penilaian data judgement atau dengan kata lain proses diulang lagi.

4. Membuat supermatriks

Dalam pembuatan supermatriks terdapat tiga macam supermatriks yang harus dilakukan yaitu unweighting supermatrix, weighting supermatrix, dan limit supermatrix.

a. Unweighted Supermatrix, terbentuk dari perbandingan berpasangan. Cara penulisannya dilakukan dengan meletakkan nilai-nilai hasil dari perhitungan perbandingan berpasangan secara terurut horizontal dari kiri ke kanan dengan menyesuaikan kode elemennya.

b. Weighted Supermatrix, merupakan unweighted supermatrix yang sudah dinormalisasikan. Hasil matriksnya berupa matriks yang nilai kolomnya sama dengan satu.

c. Limit Supermatrix, diperoleh dengan memangkatkan nilai dari weighted supermatrix dengan pangkat yang besar. Hasilnya berupa nilai antar kolom yang satu dengan kolom lainnya memiliki nilai yang sama. Limit supermatrix ini yang akan digunakan dalam proses pembobotan subkriteria/elemen.

\section{Metodologi}

\subsection{Bahan dan Alat Penelitian}

Bahan penelitian yang digunakan adalah data yang didapat dari lapangan, berupa dokumen dan data dari narasumber (agen tour \& travel) sesuai dengan informasi yang dibutuhkan dalam pembuatan produk wisata agen tour \& travel. Kemudian data yang diperoleh dari berbagai sumber penelitian yang telah ada (buku, laporan, jurnal, kuesioner dan sebagainya).

\subsection{Prosedur Penelitian}

Prosedur penelitian ini meliputi berbagai tahapan sesuai pada Gambar 1 berikut ini. 


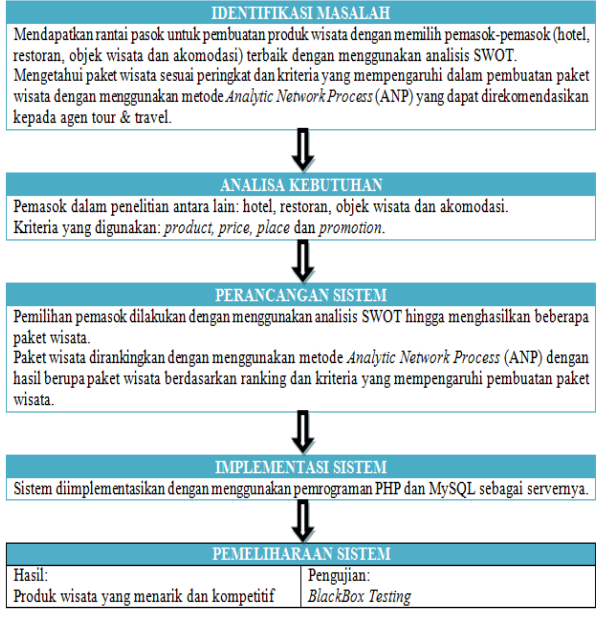

Gambar 1. Prosedur Penelitian

\subsection{Kerangka Sistem Informasi}

Kerangka sistem analisis manajemen rantai pasok untuk pembuatan produk wisata dalam agen tour \& travel menggunakan analisis SWOT dan metode Analytic Network Process(ANP) ditunjukkan pada Gambar 2.

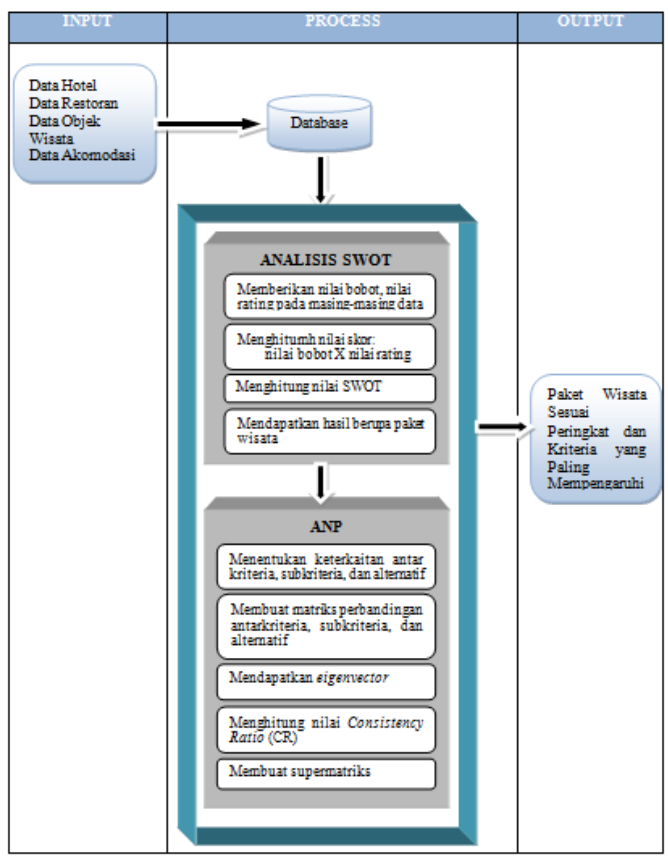

Gambar 2. Kerangka Sistem Analisis

Dari kerangka sistem di atas dapat dijelaskan bahwa awal pembuatan sistem dimulai dari pengumpulan data yang dilakukan dengan penyebaran kuesioner kepada pakar terkait yaitu manajemen agen tour \& travel untuk pemilihan pemasok (hotel, restoran, objek wisata, dan akomodasi). Data-data tersebut dimasukkan ke dalam database yang kemudian dianalisis menggunakan analisis SWOT. Setelah itu dilakukan pembobotan kriteria menggunakan metode ANP. Hasil akhirnya merupakan beberapa produk yang berupa paket wisata sesuai peringkat dan berupa kriteria yang paling berpengaruh dalam pembuatan paket wisata. Tahap selanjutnya melakukan uji validitas sistem dan data. Pengujian sistem dilakukan dengan menggunakan blackbox testing.

\subsection{Desain Sistem}

Desain sistem dibuat untuk mengetahui sistem informasi yang akan dibangun. Dalam penelitian ini, alur desain sistem yang digunakan sebagai berikut:

1. Manajemen agen tour \& travel mendaftarkan diri sebagai anggota kepada admin

2. Setelah admin memasukkan pihak manajemen agen tour \& travel tersebut ke dalam sistem, pihak manajemen dapat mengisi pertanyaan berdasarkan analisis SWOT guna membuat paket wisata

3. Jika pihak manajemen sudah melakukan pengisian pertanyaan, maka akan didapatkan hasil yang berupa paket wisata.

4. Dari paket wisata tersebut, pihak manajemen harus melakukan pengisian pertanyaan ANP guna mendapatkan ranking dari paket wisata itu sendiri

5. Hasil akhirnya, pihak manajemen dari agen tour \& travel mendapatkan paket wisata berdasarkan ranking teratas dan dapat mengetahui kriteria prioritas yang harus diperhatikan dalam pembuatan paket wisata tersebut.

\section{Hasil dan Pembahasan}

\subsection{Hasil Penelitian}

Penelitian ini menghasilkan sistem pembuatan produk wisata dengan melihat rantai pasok pada masing-masing pemasok. Pemasok tersebut antara lain hotel, restoran, objek wisata, dan akomodasi. Tujuan dari penelitian ini sendiri adalah untuk membantu pihak agen tour \& travel dalam membuat produk wisata yang menarik dan kompetitif. Beberapa agen tour \& travel yang menjadi obyek penelitian belum memiliki paket wisata. Agen membuat paket wisata berdasarkan hari dan biaya yang dimiliki calon wisatawan. Dalam pembuatan wisata yang manual tersebut banyak kendala yang dialami agen. Kendalakendala tersebut antara lain, banyaknya tempat wisata baru sehingga agen mengalami kesulitan dalam memutuskan tempat tujuan wisata, transportasi atau akomodasi masih secara manual jika kuota transportasi kurang dan atau melebihi kuota, maka calon wisatawan diikutkan transportasi dari agen lain sehingga kebutuhan akan kenyamanan calon wisatawan masih kurang.

Dalam sistem ini, analisis SWOT dipilih untuk digunakan karena analisis ini sesuai untuk memilih pemasok (hotel, restoran, objek wisata, dan akomodasi) dalam pembuatan produk wisata. Hal ini dilakukan dengan mengidentifikasi kekuatan, kelemahan, peluang dan ancaman yang terdapat pada masing-masing pemasok. Dengan menggunakan analisis SWOT ini diharapkan dapat menghasilkan pemasok yang sesuai dan menjadikan produk wisata yang akan dihasilkan nanti menjadi lebih menarik dan kompetitif. 
Metode Analytic Network Process (ANP) digunakan untuk merankingkan produk wisata berupa paket wisata agar dapat diketahui paket yang paling kompetitif dan juga dapat mengetahui kriteria yang paling berpengaruh dalam pembuatan produk wisata tersebut. Pada metode ANP, tingkat pengaruh pada setiap kriteria dan subkriteria akan dinilai. Penilaian tingkat kepentingan kriteria / subkriteria satu dengan yang lain dilakukan dengan membuat matrik perbandingan antarkriteria dan subkriteria. Tujuannya adalah untuk mengetahui prioritas kriteria dalam metode ini. Langkah selanjutnya mencari nilai CR. Nilai CR dikatakan konsisten apabila nilainya $\leq 0,1$. Jikanilai $\mathrm{CR} \geq 0,1$ maka dikatakan tidak valid karena belum konsisten. Apabila nilai CR belum konsisten, maka harus melakukan penilaian ulang. Setelah nilai CR didapat, maka dibuatlah supermatriks. Terdapat tiga tahap dalam supermatriks, yaitu: unweighted supermatix, weigthed supermatrix dan limit supermatrix. Dalam limit supermatrix didapatkan hasil akhir yang berupa prioritas paket wisata yang paling menarik dan prioritas kriteria yang paling mempengaruhi dalam pembuatan paket wisata.

Sistem aplikasi ini memberikan hasil akhir berupa berupa kriteria yang paling mempengaruhi dalam pembuatan produk wisata adalah product atau objek wisata dengan fasilitas lain seperti hotel, restoran dan akomodasi yang didapatkan saat berwisata. Kriteria product mempunyai pengaruh sebesar 0,30 dari tiga kriteria lainnya. Untuk kriteria selanjutnya yang berpengaruh dalam pembuatan produk wisata adalah price atau harga dari paket wisata tersebut. Price mempunyai pengaruh sebesar 0,28 . Sedangkan untuk paket yang paling kompetitif adalah paket 1 sebesar 0,53 .

\subsection{Analisis SWOT}

Langkah-langkah dalam SWOT antara lain:

1. Agen mengisi pertanyaan SWOT dengan memberikan nilai bobot dan nilai rating pada masing-masing pemasok, kemudian menghitung nilai skor. Hasil skor untuk SWOT pada pemasok hotel dapat dilihat pada Tabel 3.

Tabel 2. Skor SWOT Hotel

\begin{tabular}{cccc}
\hline S & Pohon Inn & $\begin{array}{c}\text { The Balava } \\
\text { Hotel }\end{array}$ & $\begin{array}{c}\text { Lava View } \\
\text { Lodge }\end{array}$ \\
\hline 1 & 5.00 & 3.00 & 3.00 \\
2 & 5.00 & 1.50 & 1.50 \\
3 & 5.00 & 3.00 & 3.00 \\
4 & 1.50 & 1.50 & 3.00 \\
5 & 1.50 & 2.00 & 5.00 \\
& 18.00 & 11.00 & 15.50 \\
\hline W & Pohon Inn & The Balava & Lava View \\
& & Hotel & Lodge \\
\hline 1 & 0.75 & 0.50 & 0.50 \\
2 & 0.75 & 0.50 & 0.50 \\
3 & 1.50 & 0.50 & 0.50 \\
4 & 0.50 & 0.50 & 0.50 \\
5 & 0.25 & 0.50 & 0.50 \\
& 3.75 & 2.50 & 2.50 \\
\hline
\end{tabular}

\begin{tabular}{cccc}
\hline O & Pohon Inn & $\begin{array}{c}\text { The Balava } \\
\text { Hotel }\end{array}$ & $\begin{array}{c}\text { Lava View } \\
\text { Lodge }\end{array}$ \\
\hline 1 & 5.00 & 3.00 & 3.00 \\
2 & 5.00 & 3.00 & 1.50 \\
3 & 5.00 & 5.00 & 3.00 \\
4 & 5.00 & 3.00 & 3.00 \\
5 & 5.00 & 3.00 & 5.00 \\
& 25.00 & 17.00 & 15.50 \\
\hline $\mathrm{T}$ & Pohon Inn & The Balava & Lava View \\
& & Hotel & Lodge \\
\hline 1 & 3.00 & 5.00 & 5.00 \\
2 & 5.00 & 5.00 & 5.00 \\
3 & 5.00 & 3.00 & 5.00 \\
4 & 5.00 & 5.00 & 5.00 \\
5 & 3.00 & 5.00 & 5.00 \\
& 21.00 & 23.00 & 25.00 \\
\hline
\end{tabular}

2. Setelah itu untuk mengetahui hotel terbaik menggunakan rumus:

$(\mathrm{S}-\mathrm{W})+(\mathrm{O}-\mathrm{T})$

Untuk mengetahui hotel terbaik dapat dilihat pada Tabel 3.

Tabel 3. Hotel Terbaik

\begin{tabular}{clllllc}
\hline No & $\begin{array}{l}\text { Nama } \\
\text { Hotel }\end{array}$ & $\mathrm{S}$ & $\mathrm{W}$ & $\mathrm{O}$ & $\mathrm{T}$ & $(\mathrm{S}-\mathrm{W})+(\mathrm{O}-\mathrm{T})$ \\
\hline 1 & $\begin{array}{l}\text { Pohon } \\
\text { Inn }\end{array}$ & 18 & 3.75 & 25 & 21 & 18.25 \\
2 & $\begin{array}{l}\text { The } \\
\text { Balava }\end{array}$ & 11 & 2.50 & 17 & 23 & 2.5 \\
3 & $\begin{array}{l}\text { Hotel } \\
\text { Lava } \\
\text { View } \\
\text { Lodge }\end{array}$ & 15.5 & 2.50 & 21 & 25 & 9.00 \\
\hline
\end{tabular}

3. Langkah 1 dan langkah 2 dilakukan juga pada pemasok-pemasok lain (restoran, objek wisata, dan akomodasi).

4. Langkah selanjutnya merupakan pemilihan pemasok untuk dijadikan suatu paket wisata. Hal tersebut dilakukan dengan memilih jumlah total terbanyak yang berasal dari rekomendasi yang telah diisi para agen.

\subsection{Analytical Network Process}

Langkah-langkah yang dilakukan antara lain:

1. Penentuan keterkaitan antar kriteria / subkriteria.

Penentuan keterkaitan antarkriteria mengacu pada hasil analisis SWOT yang telah dilakukan sebelumnya. Analasis SWOT menghasilkan beberapa paket wisata. Paket-paket wisata tersebut kemudian diperingkatkan dengan menghitung keterkaitan kriteria-kriteria yang telah ditentukan. Kriteria-kriteria tersebut antara lain product, price, place, promotion.

2. Membuat perbandingan berpasangan

kriteria/subkriteria dan mencari nilai eigen.

Perbandingan berpasangan dilakukan baik untuk kriteria ataupun subkriteria. Misal, mencari keterkaitan pada kriteria product dengan price, product dengan place, product dengan promotion, price dengan place, price dengan promotion, dan place dengan promotion. Penilaian perbandingan diterapkan dengan mengacu kepada skala Saaty pada Tabel 4. 
$\underline{\text { Tabel 4. Matriks perbandingan antar kriteria }}$

Kriteria Product Price Place Promotion

\begin{tabular}{lcccc}
\hline Product & 1 & 2.00 & 4.00 & 3.00 \\
Price & 0.50 & 1 & 3.00 & 2.00 \\
Place & 0.25 & 0.33 & 1 & 0.50 \\
Promotion & 0.33 & 0.50 & 2.00 & 1 \\
\multicolumn{1}{c}{ Jumlah } & 2.08 & 3.83 & 10.00 & 6.50 \\
\hline
\end{tabular}

Jika perbandingan berpasangan sudah ditentukan, maka tahap selanjutnya adalah melakukan perhitungan agar didapatkan nilai eigen. Caranya adalah dengan melakukan normalisasi kemudian mencari nilai ratarata tiap baris. Jika semua matriks memiliki jumlah yang sama yaitu bernilai 1, maka matriks telah dinormalisasikan (Tabel 5).

Tabel 5. Matriks normalisasi

\begin{tabular}{|l|c|c|c|c|c|}
\hline \multicolumn{1}{|c|}{ Kriteria } & Product & Price & Place & Promotion & $\begin{array}{c}\text { Eigen } \\
\text { vector }\end{array}$ \\
\hline Product & 0.48 & 0.52 & 0.40 & 0.46 & 0.47 \\
\hline Price & 0.24 & 0.26 & 0.30 & 0.31 & 0.28 \\
\hline Place & 0.12 & 0.09 & 0.10 & 0.08 & 0.10 \\
\hline Promotion & 0.16 & 0.13 & 0.20 & 0.15 & 0.16 \\
\hline \multicolumn{1}{|c|}{ Jumlah } & 1 & 1 & 1 & 1 & \\
\hline
\end{tabular}

3. Melakukan perhitungan Consistency Ratio (CR)

\begin{tabular}{l|c|c|c|c|c|c|c|c|}
\hline Kriteria & Prod & Price & Place & Prom & Hasil & $\lambda_{\max }$ & CI & CR \\
\hline Prod & 0.47 & 0.56 & 0.40 & 0.48 & 1.91 & 1.02 & 0.01 & 0.01 \\
\hline Price & 0.23 & 0.28 & 0.30 & 0.32 & 1.14 & 1.02 & & \\
\hline Place & 0.12 & 0.09 & 0.10 & 0.08 & 0.39 & 1.02 & & \\
\hline Prom & 0.16 & 0.14 & 0.20 & 0.16 & 0.66 & 1.03 & & \\
\hline \multicolumn{7}{|c|}{ Jumlah } \\
\hline
\end{tabular}

\section{Pembuatan supermatrix}

Dalam pembuatan supermatriks terdapat tiga macam supermatriks yang harus dilakukan yaitu unweighted supermatrix, weighted supermatrix, dan limit supermatrix.

a.Unweighted Supermatrix, terbentuk dari perbandingan berpasangan. Cara penulisannya dilakukan dengan meletakkan nilai-nilai hasil dari perhitungan perbandingan berpasangan secara terurut horizontal dari kiri ke kanan dengan menyesuaikan kode elemennya.

Tabel 6. unweighted supermatrix.

\begin{tabular}{|l|c|c|c|c|}
\hline \multicolumn{1}{|c|}{ Kriteria } & Product & Price & Place & Promotion \\
\hline Product & 1 & 0.54 & 0.16 & 0.30 \\
\hline Price & 0.50 & 1 & 0.12 & 0.20 \\
\hline Place & 0.25 & 0.33 & 1 & 0.16 \\
\hline Promotion & 0.33 & 0.50 & 2.00 & 1 \\
\hline
\end{tabular}

b. Weighted Supermatrix, merupakan unweighted supermatrix yang sudah dinormalisasikan. Hasil matriksnya berupa matriks yang nilai kolomnya sama dengan satu.

Tabel 4.12 Weighted supermatrix

\begin{tabular}{|l|c|c|c|c|c|c|}
\hline Kriteria & Product & Price & Place & Promotion & Hasil & Hasil/jumlah \\
\hline Product & 0.47 & 0.15 & 0.02 & 0.05 & 0.69 & 0.30 \\
\hline Price & 0.32 & 0.28 & 0.01 & 0.05 & 0.64 & 0.28 \\
\hline Place & 0.25 & 0.08 & 0.10 & 0.03 & 0.46 & 0.20 \\
\hline Promotion & 0.29 & 0.07 & 0.01 & 0.16 & 0.53 & 0.23 \\
\hline \multicolumn{7}{|c|}{ Jumlah } \\
\hline
\end{tabular}

c.Limit Supermatrix, diperoleh dengan memangkatkan nilai dari weighted supermatrix dengan pangkat yang besar. Hasilnya berupa nilai antar kolom yang satu dengan kolom lainnya memiliki nilai yang sama. Limit supermatrix ini yang akan digunakan dalam proses pembobotan subkriteria/elemen.

Tabel 4.13. Limit supermatrix

\begin{tabular}{|l|c|c|c|c|c|c|}
\hline Kriteria & Product & Price & Place & Promotion & Jumlah & Prioritas \\
\hline Product & 0.08 & 0.08 & 0.06 & 0.07 & 0.30 & 1 \\
\hline Price & 0.09 & 0.08 & 0.06 & 0.06 & 0.28 & 2 \\
\hline Place & 0.06 & 0.06 & 0.04 & 0.05 & 0.21 & 4 \\
\hline Promotion & 0.07 & 0.06 & 0.05 & 0.05 & 0.23 & 3 \\
\hline Jumlah & 0.30 & 0.28 & 0.21 & 0.23 & 1.02 & \\
\hline
\end{tabular}

5. Menghitung nilai alternatif

Cara ntuk mengitung nilai alternatif hampir sama dengan cara menghitung supermatrix kriteria yaitu dengan melalui tiga tahap supermatrix. Yang berbeda hanya pada awal perhitungan yaitu perhitungan unweighted supermatrix pembetukan yang dilakukan dengan cara mengambil rata-rata geometri yang ada pada setiap alternatif. Untuk mendapatkan rata-rata geometri dilakukan dengan menggunakan rumus :

$$
\mathrm{G}: \quad \sqrt[n]{X_{1} x X_{2} x X_{3} x X_{n}}
$$

Dimana:

$\mathrm{X} 1$ : nilai perbandingan berpasangan normalisasi ke-1

$\mathrm{X} 2$ : nilai perbandingan berpasangan normalisasi ke-n

n : banyaknya sampel

Tabel 4.14 Hasil dari unweighted supermatrix alternatif

\begin{tabular}{|l|c|c|c|c|}
\hline Kriteria & Product & Price & Place & Promotion \\
\hline Paket 1 & 0.60 & 0.54 & 0.50 & 0.30 \\
\hline Paket 2 & 0.20 & 0.30 & 0.25 & 0.16 \\
\hline Paket 3 & 0.20 & 0.16 & 0.25 & 0.24 \\
\hline
\end{tabular}

Untuk proses selanjutnya yaitu menghitung proses weigthed supermatrix yang dilakukan dengan cara mengkalikan matriks unweigthed supermatrix dengan eigenvector bobot kriteria. Dengan catatan bahwa nilai kolom pada matriks yang dihasilkan adalah 1 . Sedangkan pada limit supermatrix dihitung dengan mengkalikan weigthed supermatrix dengan dirinya sendiri dengan hasil berupa nilai baris sama dengan nilai kolom. Dari limit supermatrix tersebut dapat diketahui prioritas alternatif sebagai hasilnya. Hasil dari alternatif dalam penelitian ini sendiri berupa 
prioritas kriteria yang paling berpengaruh dalam pembuatan paket wisata.

Setelah melalui analisis SWOT dan perhitungan ketergantungan kriteria di dalamnya dengan menggunakan ANP, hasil yang didapat berupa paket wisata berdasarkan peringkat masing-masing. Dalam penelitian ini, paket wisata 1 menempati peringkat pertama dengan nilai sebesar 0,53. Kemudian paket wisata 3 menempati peringkat kedua dan paket wisata 2 menempati peringkat ketiga. Sedangkan untuk kriteria yang paling berpengaruh dalam pembuatan paket wisata adalah kriteria product dengan nilai sebesar 0,30. Kemudian kriteria selanjutnya yang berpengaruh berdasarkan peringkat ialah kriteria price, kriteria promotion, dan diperingkat terakhir adalah kiriteria place.

Kelemahan dari sistem ini adalah kerangka analisis SWOT yang digunakan dalam penelitian belum memiliki kerangka pasti dalam menentukan kriteria untuk masing-masing indikator S-W-O-T. Kriteria-kriteria tersebut digunakan tidak hanya untuk analisis SWOT saja tetapi untuk perhitungan pada ANP. Jika kriteria yang digunakan masih belum memiliki kerangka atau rule yang pasti, hal ini mengakibatkan lemahnya tingkat akurasi yang dihasilkan.

\section{Kesimpulan}

Penelitian yang dilakukan menggunakan analisis SWOT yang digunakan dalam penilaian dan pemilihan hotel, restoran, objek wisata, dan akomodasi yang tebaik untuk mendapatkan produk berupa paket wisata yang menarik, kompetitif dan dapat direkomendasikan kepada pihak agen tour \& travel. Dalam penelitian ini, metode ANP digunakan sebagai metode atau cara untuk mencari dan mengetahui hasil paket wisata sesuai prioritas atau ranking. Metode tersebut juga digunakan untuk mengetahui kriteria-kriteria yang paling berpengaruh dalam pembuatan produk berupa paket wisata. Dengan menggunakan analisis SWOT dalam penelitian ini dapat diketahui bahwa kriteria yang paling mempengaruhi dalam pembuatan produk wisata adalah product atau objek wisata dengan fasilitas lain seperti hotel, restoran dan akomodasi yang didapatkan saat berwisata karena memenuhi syarat nilai Concistency Ratio $\leq 0,1$ dengan nilai CR sebesar 0,01 . Kriteria product mempunyai pengaruh sebesar 0,30 dari tiga kriteria lainnya. Untuk kriteria selanjutnya yang berpengaruh dalam pembuatan produk wisata adalah price atau harga dari paket wisata tersebut. Price mempunyai pengaruh sebesar 0,28 . Sedangkan untuk paket yang paling kompetitif adalah paket 1 sebesar 0,53 .

\section{Daftar Pustaka}

Agung, Y., 1996. Edisi Revisi: Pengantar Ilmu Pariwisata, Bandung: Angkasa.

Cheyne, J., Downes, M., and Legg, S., 2006. Travel Agents vs Internet: What Influences Travel Customer Choices?, Journal of Vacation Marketing, 12 (1), 41-57.

David, F.R., 2008. Manajemen Strategis. Edisi Sepuluh, Jakarta: Penerbit Salemba Empat.

Dewayana, S. T., dan Budi, A., 2009. Pemilihan Pemasok Cooper Rod Menggunakan Metode ANP, Jurnal Jurusan Teknik Industri Universitas Diponegoro, IV(3), pp 212-217.

Fahmi, I., 2014. Manajemen Strategis Teori dan Aplikasi, Cetakan 2, Bandung: CV. Alfabeta.

Garvin dan David, 2001. Managing Quality: Manajemen Alutu Terpadu (Fotal Quality Management), Jakarta: Ghalia Indonesia.

Jharkaria, S., dan Shankar, R., 2005. Selection of Logistics Service Provider: An analytic network process (ANP) approach, The International Journal of Management Science, 35, hal 274-289.

Khodaverdi, K., Faghih, A., dan Eslami, E., 2008. A Fuzzy Analytic Network Process Approuch to Evaluate Concrete Waste Management Options, USA: University Columbia.

Mike, R., 2006. 120 Solusi Mengelola Keuangan Pribadi, Jakarta: Alex Media Komputindo.

Ng, Wang. L., 2008. An Efficient and Simple Model for Multiple Criteria Supplier Selection Problem, European Journal of Operational Research, 186, pp. 1059-1067.

Rangkuti, F., 2006. Analisis SWOT Teknik Membedah Kasus Bisnis, Jakarta: PT. Gramedia Pustaka Utama.

Rangkuti, F., 2009. Strategi Promosi yang Kreatif dan Analisis Kasus Integrated Marketing Communication, Jakarta: PT. Gramedia Pustaka Utama.

Saaty, T. L., 1996. The Analytic Hierarchy Process, New York: McGraw-Hill.

Undang-Undang Republik Indonesia Nomor 10 tahun 2009. Kepariwisataan.

Widjajanta, B., dan Widyaningsih, A., 2007. Mengasah Kemampuan Ekonomi, Bandung: CV. Citra Praya.

Yevstafyev. V. N dan Yevstafyev. N. E, 2015. Factors Effecting The Partnership Between Tour Operators and Travel Agents in Rusia, International Conference on Applied Economics, ICOAE 2015, 24 July 2015, Kazan, Rusia. 